\title{
Management and control of parasites on dairy farms in northwestern region of São Paulo state
}

\author{
Manejo e controle de parasitas em fazendas leiteiras da região noroeste paulista \\ Cecília José Veríssimo ${ }^{1 *}$; Flávia Vasques²; Keila Maria Roncato Duarte; Valdinei Tadeu Paulino ${ }^{1}$; \\ Luis Alberto Ambrósio ${ }^{1}$

\begin{abstract}
${ }^{1}$ Secretaria de Agricultura e Abastecimento do Estado de SP, Instituto de Zootecnia - IZ, Agência Paulista de Tecnologia dos Agronegócios - APTA, Nova Odessa, SP, Brasil

${ }^{2}$ Coordenadoria de Assistência Técnica Integral - CATI, Secretaria de Agricultura e Abastecimento do Estado de São Paulo, Votuporanga, SP, Brasil
\end{abstract}

Received April 8, 2016

Accepted June 13, 2016

\begin{abstract}
Dairy cattle farming is of great economic and social importance in all Brazilian's regions. Parasites can reduce milk productivity, especially the tick Rhipicephalus (Boophilus) microplus. This study consisted of a questionnaire answered by 40 milk producers in the northwestern region of the State of São Paulo. The aim was to ascertain how these producers controlled ticks and other parasites. Very many of them knew nothing about the biological cycle of the cattle tick or about strategic control or acaricide efficacy tests. The majority (87.5\%) controlled ticks at a high frequency, without technical criteria and care to apply the acaricide. Spraying was the most used mode of acaricide application (95\%) and endectocides were used by $45 \%$. Cattle tick fever was the harm most associated with ticks (87.5\%) followed closely by screwworm (77.5\%). However, $65 \%$ were satisfied with their tick control. About the control of others parasites, all dewormed at least twice a year their animals; $65 \%$ were controlling horn fly; $40 \%$ had problems with screwworm. The interviewers had in general good level of education and the farms generally exhibited a high degree of technology for milk production on pasture because half of them received technical assistance frequently.
\end{abstract}

Keywords: Cattle, milk, production, questionnaire, sustainable, tick.

\section{Resumo}

A bovinocultura leiteira é de extrema importância econômica e social em todas as regióes brasileiras. Os parasitas podem reduzir a produção leiteira, especialmente o carrapato Rhipicephalus (Boophilus) microplus. Este trabalho consistiu em um questionário respondido por 40 produtores de leite da região noroeste do Estado de São Paulo, com o objetivo de saber como os produtores controlam carrapatos e outros parasitas. Grande parte deles não conhecia o ciclo biológico do carrapato do boi nem o controle estragégico e o teste de eficácia de carrapaticidas. A maioria (87,5\%) controlava o carrapato com alta frequência, sem critérios técnicos e cuidados na aplicação do carrapaticida. A aspersão foi o modo de aplicação mais usado (95\%) e endectocidas eram utilizados por $45 \%$. Tristeza parasitária bovina foi o prejuízo mais associado ao carrapato $(87,5 \%)$, seguido de perto pela bicheira $(77,5 \%)$. No entanto, $65 \%$ estavam satisfeitos com o controle do carrapato. A maioria $(82,5 \%)$ criava gado mestiço. Em relação ao controle de outros parasitas, todos vermifugavam seus animais pelo menos duas vezes por ano; $65 \%$ deles controlava a mosca-do-chifre; $40 \%$ têm problemas com bicheira. Os entrevistados, de forma geral, tinham bom nível educacional, e as fazendas geralmente exibiam alto grau de tecnologia em produção de leite a pasto, porque metade delas recebia assistência técnica constante de um programa estatal que incentiva a produção leiteira sustentável.

Palavras-chave: Bovino, leite, produçáo, questionário, sustentável, carrapato.

*Corresponding author: Cecília José Veríssimo. Centro de Pesquisa e 


\section{Introduction}

The northwestern region of the State of Sáo Paulo is a major dairy production areas, according to an agriculture and livestock census conducted in this State. This region is characterized by mixed cattle-rearing (dairy and meat production), with a herd of around 1.240 million head, which represents $23 \%$ of the herd of the State of São Paulo, and also by family-run smallholdings, low-fertility soils and sugar-cane monoculture (SÃO PAULO, 2008).

The dairy production chain plays an important role in the Brazilian economy, through creating new jobs, wealth and taxes. Moreover, it has social importance in that it keeps small and medium-sized farms in operation in rural areas and maintains these farmers' quality of life. The growing population and its demand for food have led to a need to increase milk production. New requirements for quality standards for milk and dairy products and for food safety have led to a need for improvement of milk production quality. These needs, along with maintaining fair prices, allied to sustainable production, represent technical, economic, social and political challenges.

Milk production costs may be high because of sanitary management requirement, and $R$. (B.) microplus control can be highlighted in this regard. This is one of the most harmful ectoparasites towards susceptible cattle, especially those of Holstein descendent (UTECH et al., 1978). It causes economic damage, such as reducing the weight gain, meat and milk production, fertility and leather quality, and increasing the occurences of herd diseases, pathogen transmission, skin damage, animal stress, mortality, etc (PEREIRA et al., 2008). The economic losses may be more than U\$ 3 billion per year in Brazil, according to Grisi et al. (2014). The expenditure on antiparasitic products is very high, although they do not always have effective results. As cited by Rocha et al. (2006), this situation is possibly worsening with the increasing size of dairy herds, given that the epidemiological situation and degree of tick control have not improved over the last few years. Rodrigues \& Leite (2013) studied a dairy herd in Minas Gerais and estimated that tick infestation gave rise to loss of milk production of $2.7 \%$. However, the resistance to ticks presenting in Bos indicus cattle and their crosses can be used in production systems with less use of chemical products, without prejudice to milk production (MADALENA, 2008).

The cattle tick, $R$. (B.) microplus, is a monoxenic tick. Its life cycle has two complementary phases: a free-living phase that begins with detachment of the teleogyne (engorged female tick) from the host such that it fall to the ground in the pasture; and a parasitic phase lasting around 21 days, which begins when the larva becomes attached to the host's skin (PEREIRA et al., 2008). The free-living phase depends mainly on the environmental temperature and relative humidity of the air (VERÍSSIMO, 2015). Knowledge of tick biology among farmers is an advantage for improving tick control. However, in surveys already conducted in Brazil, it has been found that most farmers either have no knowledge or only partial knowledge of the biological cycle of this tick. They apply chemical products incorrectly, using incorrect equipment and at a higher frequency than needed, and especially, without technological practices (SANTOS et al., 2000, 2009;
MENDES et al., 2008; BERTOLUCCI, 2010; AMARAL et al., 2011a, b; ROCHA et al., 2006, 2011). Among the most dangerous consequences of incorrect use of acaricides are fast development of resistant strains (SANTOS et al., 2009; MENDES et al., 2011; FAZA et al., 2013) and presence of chemical residues. These residues can be detected in cattle tissues (REZENDE et al., 2013), in workers who do the applications (SILVA et al., 2012) and in the environment (KUNZ \& KEMP, 1994).

Several surveys on tick control have been conducted among dairy farmers in the State of Minas Gerais, but few detailed questionnaires covering the production system and control of parasites in the State of São Paulo State have ever been implemented. In the State of São Paulo, Mendes et al. (2008) conducted a survey among 40 dairy farmers in the southeast of the State, in a region near the Paraiba river valley, close to the municipality of Pindamonhangaba, more than $500 \mathrm{~km}$ from the region of the present study. In the northwest of the State, Mendes et al. (2011) interviewed only five individuals who were responsible for farms where ticks were collected for efficiency tests.

The present study had the aim of finding out about production systems and parasite control in dairy farms in the northwestern region of the state of São Paulo, with emphasis on control measures that were used against the tick Rhipicephalus (Boophilus) microplus. The results are discussed in the light of the current situation of chemical control failure, and viable alternatives other than chemical control are proposed.

\section{Materials and Methods}

Forty dairy farmers in 14 municipalities (Fernandópolis, 12; Votuporanga, 4; Valentim Gentil, 4; Estrela d'Oeste, 3; Guarani d'Oeste, 3; Ouroeste, 3; Meridiano, 2; Pedranópolis, 2; São João das Duas Pontes, 2; and Aspasia, Cosmorama, Indiaporã, Macedônia and Populina, 1 each), all located in the northwestern region of the State of São Paulo, were interviewed in the year of 2013 with the aid of a questionnaire. Half of them were participating in the CATI Milk Project, a program run by the official body responsible for rural extension education and technical assistance for farmers in the State of São Paulo, which is linked to the Department of Agriculture and Supply of the State of São Paulo (PAGANI, 2012).

To be able to participate in this program, farmers must make a commitment to adopt some technological practices, including rotational grazing, pasture fertilization, electric fences, highly nutritive pasture, animal identification through zootechnical records and artificial insemination (PAGANI, 2012).

The northwestern region of the State of São Paulo has a tropical semi-humid climate, with two well-defined seasons: dry winter and rainy summer. The overall average temperature ranges from 37 to $15^{\circ} \mathrm{C}$, from the summer to the winter, respectively, with average annual temperature of $33{ }^{\circ} \mathrm{C}$ and rainfall of $999 \mathrm{~mm}$ (data from the Meteorological Center of the Camilo Castelo Branco University, Fernandópolis, State of São Paulo, Brazil).

The questionnaire was composed of almost 100 questions, divided into five sections relating to: 1) characterization of the farm and herd; 2) owner and farm management; 3) knowledge of 
tick biology, control and resistance; 4) control of other parasites; and 5) technical assistance and acaricide efficiency test.

All of the questionnaires applied were approved in relation to the coherence of the information given. Some questions accepted more than one answer.

Descriptive statistics were used to present a summary of the quantitative information on the distribution of values regarding the continuous or discrete variables contained in the responses to this questionnaire. Where possible and appropriate, we used the statistical parameters of the frequency distributions of the variables. Estimates for the central trends of distributions were expressed as means and medians. Estimates for the dispersion (or variance) were represented by the standard deviation, error of the mean, minimum and maximum values and quartiles. The Minitab 13 software (MINITAB, 2000) was used for the calculations of the statistical analyses.

\section{Results}

The results relating to the size of the farms, the length of time for which the farm had been involved in milk-producing activity, percentage of the family income that milk accounted for, stocking rate in the rainy season and numbers relating to the categories of the animals are listed in Table 1 . The average milk production was 12 liters/day/cow.

Among the major grass types that were declared as constituting the grazing pastures, the genus Urochloa (sin. Brachiaria) was the one most cited (46\%), followed by Megathyrsus (sin. Panicum) (41.5\%) and Cynodon (12.5\%). One quality factor observed was the presence of high proportions of vegetation cover (80 to $100 \%$ ) on $95 \%$ of the farms studied, by visual observation of the ratio between leaves and stems of the paddocks.

The rotational grazing system was the one mostly used by the farmers $(70 \%)$, using electrified fences (95\%). The period for which each pasture area was used ranged from 1 to 5 days, and the majority of the responses (93\%) reported one-day periods. The resting period ranged from 15 to 34 days (average of 27 days).

The majority $(95 \%)$ of the farms applied fertilizer to their pastures. Cover fertilization was applied by $80 \%$ of them, soon after the animals had been taken out of the paddock, and urea was the fertilizer chosen by $80 \%$ of the producers in this fertilization procedure.

Most of the owners (80\%) kept zootechnical records, and 65\% of them identified their animals using ear tags. Ninety percent of the farmers had a bull on the farm, but $60 \%$ of them use it for "transfer", in case artificial insemination did not work. Forty percent used FTAI (fixed-time artificial insemination).

All dairy farmers adopted the same production system: pasture alone in the summer and supplementation with feed in a trough during the dry season. Most of them produced their own bulk supplementation feed (95\%), composed of sugar cane $(45 \%)$ or sugar cane and silage (45\%). They all complemented the feed with concentrate, mostly bought locally $(57.5 \%)$. All the farmers gave mineral salt to the animals all year long. Artificial watering devices accounted for $78 \%$ of the water given. All the farms had shaded areas available for the animals and, of these, $87.5 \%$ comprised natural shade, under trees.

The characterization of the 40 farms according to their production system and management can be seen in Table 2 .

The responses regarding knowledge of tick biology, control management and use of acaricides are shown in Table 3.

The responses relating to problems found in controlling other parasites are shown in Table 4.

With regard to technical assistance, $70 \%$ of the farmers responded that they often used it and $22.5 \%$ that they rarely used it. Only $7.5 \%$ did not have any technical assistance. When asked about training and learning new information, 32\% answered that they participated in courses and lectures, while 19\% learned from other producers, $12 \%$ from the internet, $12 \%$ from books or magazines, $11 \%$ from fairs or exhibitions, $7 \%$ from radio or TV programs and $7 \%$ from the salesperson at the farming supplies store.

Table 1. Quantitative descriptive parameters of dairy farms in the northwestern region of São Paulo, Brazil (2013).

\begin{tabular}{|c|c|c|c|c|c|c|c|c|c|}
\hline Variables & $\mathbf{N}^{*}$ & Average & $\begin{array}{l}\text { Standard } \\
\text { deviation }\end{array}$ & $\begin{array}{c}\text { Average } \\
\text { error }\end{array}$ & Minimum & Maximum & Q1 & Median & Q3 \\
\hline Total area & 40 & 57.7 & 65.2 & 10.3 & 2.4 & 290.4 & 16.9 & 27.6 & 60.5 \\
\hline Milk production area & 40 & 43.4 & 47.0 & 7.4 & 2.4 & 232.3 & 14.3 & 23.5 & 48.8 \\
\hline Pasture area & 40 & 32.5 & 40.6 & 6.4 & 2.3 & 180 & 9.8 & 19.5 & 33.2 \\
\hline Crop area & 37 & 10.3 & 16.8 & 2.8 & 1.2 & 96.8 & 2.4 & 4.8 & 10.3 \\
\hline Forest area & 37 & 3.9 & 4.7 & 0.8 & 0.1 & 21.78 & 1 & 2.4 & 4.84 \\
\hline Time in milk activity (years) & 40 & 22.1 & 15.7 & 2.5 & 2 & 60 & 10 & 20 & 33.7 \\
\hline$\%$ of family income from milk & 40 & 51.3 & 25.6 & 4.0 & 20 & 100 & 30 & 51 & 70 \\
\hline $\begin{array}{l}\text { Stocking rate in rainy season } \\
\text { (animals/ha) }\end{array}$ & 40 & 6.1 & 4.6 & 0.7 & 0.1 & 15 & 2 & 6 & 9.4 \\
\hline Cows & 40 & 43.9 & 31.6 & 5 & 3 & 130 & 20 & 40 & 60 \\
\hline Heifers & 36 & 26.9 & 36.2 & 6.0 & 3 & 210 & 6 & 18 & 30 \\
\hline Calves & 38 & 19.6 & 13.7 & 2.2 & 3 & 57 & 6 & 17.5 & 30 \\
\hline Males & 36 & 17.7 & 12.0 & 2.0 & 3 & 49 & 7 & 14 & 26.5 \\
\hline Total animals & 40 & 102.5 & 78.9 & 12.5 & 5 & 392 & 42 & 85.5 & 143 \\
\hline
\end{tabular}

${ }^{*}$ Categories with fewer than 40 are due to loss of response. Q1 - First quartile. Q3 - Third quartile. N - Number. 
Table 2. Characterization of 40 dairy farms in the northwestern region of the state of São Paulo according to milk production activity, owner's education, production level and management system.

\begin{tabular}{|c|c|c|}
\hline Characteristic & Description & N (\%) \\
\hline \multirow{3}{*}{ Education level of the owner } & University level & $16(40 \%)$ \\
\hline & Elementary school & $12(30 \%)$ \\
\hline & High school & $12(30 \%)$ \\
\hline \multirow{2}{*}{ Permanent employees } & Yes & $27(67.5 \%)$ \\
\hline & No & $13(32.5 \%)$ \\
\hline \multirow{3}{*}{ Labor } & Employees & $25(62.5 \%)$ \\
\hline & Family members & $12(30 \%)$ \\
\hline & Both & $3(7.5 \%)$ \\
\hline \multirow{4}{*}{ How many employees } & 1 & $16(59.26 \%)$ \\
\hline & 2 & $7(25.92 \%)$ \\
\hline & 3 & $2(7.41 \%)$ \\
\hline & 4 & $2(7.41 \%)$ \\
\hline \multirow{2}{*}{ Temporary labor } & Yes & $25(62.5 \%)$ \\
\hline & No & $15(37.5 \%)$ \\
\hline \multirow{2}{*}{ Main activity } & Milk and beef & $26(65 \%)$ \\
\hline & Milk & $14(35 \%)$ \\
\hline \multirow{2}{*}{ Milk is the principal source of income } & Yes & $21(52.5 \%)$ \\
\hline & No & $19(47.5 \%)$ \\
\hline \multirow{5}{*}{ Main breeds of the cows } & European x Gir (Zebu) & $29(72.5 \%)$ \\
\hline & European x Nelore (Zebu) & $4(10 \%)$ \\
\hline & Jersey & $4(10 \%)$ \\
\hline & Holstein or $7 / 8$ Holstein $\times 1 / 8$ Zebu & $2(5 \%)$ \\
\hline & Simmental & $1(2.5 \%)$ \\
\hline \multirow{3}{*}{ Daily milk production range } & $200-500 \mathrm{~L}$ & $17(42.5 \%)$ \\
\hline & 1-199L & $15(37.5 \%)$ \\
\hline & $>500 \mathrm{~L}$ & $8(20 \%)$ \\
\hline \multirow{2}{*}{ Type of milking } & Mechanical & $35(87.5 \%)$ \\
\hline & Manual & $5(12.5 \%)$ \\
\hline \multirow{2}{*}{$\begin{array}{l}\text { Do you bring in a lot of animals from outside } \\
\text { of the herd? }\end{array}$} & No & $24(60 \%)$ \\
\hline & Yes & $16(40 \%)$ \\
\hline \multirow{2}{*}{ What do you do with animals newly acquired? } & Immediately incorporated into the herd & $37(92.5 \%)$ \\
\hline & Quarantine & $3(7.5 \%)$ \\
\hline \multirow{2}{*}{ Calf mortality rate } & $\leq 1 \%$ & $34(85 \%)$ \\
\hline & $>1 \%$ & $6(15 \%)$ \\
\hline \multirow{6}{*}{ Vaccines } & Foot and mouth disease & $40(100 \%)$ \\
\hline & Brucellosis & $40(100 \%)$ \\
\hline & Clostridiosis & $39(97.5 \%)$ \\
\hline & Leptospirosis & $12(30 \%)$ \\
\hline & IBR-BVD & $11(27.5 \%)$ \\
\hline & Others & $9(22.5 \%)$ \\
\hline
\end{tabular}

$\mathrm{N}$ - Number. \% - Percentage.

The majority of the farmers (95\%) were well-informed about the problem of tick resistance to acaricide products and only $5 \%$ said that they knew nothing about the issue. Only 10\% knew about or had implemented the acaricide efficiency test; $40 \%$ knew about the test but had never used it and 50\% had never heard about it.

Only 10\% of the owners (four farmers) had already implemented the acaricide efficiency test. The products with low efficiency were, in decreasing order, based upon active molecules: pyrethroids (34\%); mixed chemical compounds (32\%); amidines (17\%) and organophosphate compounds (17\%). On the other hand, the products with high efficiency were all $100 \%$ mixed formulas (organophosphate plus pyrethroids). Two farmers implemented efficiency tests 30 days before the interview; one did this six months before the interview and one did this two years before the interview.

\section{Discussion}

The recently adopted Brazilian Forest Code, based on law no. $11.326 / 2006$, states that small farms consist of one to four fiscal modules, and that the area of each module is defined for each municipality (FERREIRA, 2015). Thus, among the municipalities in the area of the present study (SÃO PAULO, 2014), the majority of the farms can be classified as rural smallholdings, with an average 
Table 3. Characterization of 40 dairy farms in the northwestern region of the State of São Paulo relating to knowledge and perception of tick biology, control management and use of acaricides.

Questions
R. (B.) microplus tick is a problem on the farm

Are you satisfied with your tick control?

Do you know about the biological cycle of cattle ticks?

Do you know about strategic control?

Do you ever see any natural enemies of ticks?

Which ones?

Are your pastures favorable towards ticks?

What favors ticks?

Do you have pastures unfavorable towards ticks?

What makes them unfavorable towards the presence of ticks?

Damage associated with ticks

Season of highest incidence

How often do you apply acaricide?

Who applies the acaricide?

Criteria for acaricide application

Acaricide is applied to

Parts of animal body most often sprayed

Are the animals restrained for acaricide application?

Use of personal protection equipment

The acaricide is changed

\section{Responses}

Yes

No

It depends on the season

Yes

No

No

Yes

Don't know

Yes, know and apply Yes, know but don't apply

Yes

No

Egrets, chickens and other birds

Yes

No

Grass types like Mombaça, Tifton, Tanzania or Brachiaria

Lowered pastures

Old pastures without fertilizer application

Pastures near forest

Long grass

Others

Yes

No

Pastures near forests

Newly-formed pastures

Other responses

Tick fever

Screwworm

Mortality

Weight loss

Milk loss

Summer

Fall

Winter

Spring

Very often (every 7-30 days)

Often (every 60 days)

Rarely (more than every 90 days)

Hired worker

Owner

Whenever ticks are visible

Strategic control

All animals on the same occasion

Some animals or batches

Whole body

Parts of the body that are most parasitized

No
Yes

Yes

No

Yes

When it fails

After each application

Without criteria

In accordance with the efficacy test

N (\%)

$18(45 \%)$

$13(32.5 \%)$

$9(22.5 \%)$

26 (65\%)

$14(35 \%)$

$33(82.5 \%)$

7 (17.5\%)

$30(75 \%)$

$6(15 \%)$

$4(10 \%)$

$37(92.5 \%)$

$3(7.5 \%)$

$40(100 \%)$

$30(75 \%)$

$10(25 \%)$

$16(53.3 \%)$

$4(13.3 \%)$

$4(13.3 \%)$

4 (13.3\%)

$2(6.6 \%)$

$6(20 \%)$

$27(67.5 \%)$

$13(32.5 \%)$

$13(48.1 \%)$

$8(29.6 \%)$

$19(70.4 \%)$

$35(87.5 \%)$

$31(77.5 \%)$

$20(50 \%)$

$18(45 \%)$

$18(45 \%)$

38 (95\%)

$5(12.5 \%)$

$1(2.5 \%)$

$1(2.5 \%)$

$35(87.5 \%)$

$3(7.5 \%)$

2 (5\%)

22 (55\%)

18 (45\%)

37 (92.5\%)

$3(7.5 \%)$

$20(50 \%)$

$20(50 \%)$

$35(87.5 \%)$

$5(12.5 \%)$

$31(77.5 \%)$

$9(22.5 \%)$

$35(87.5 \%)$

$5(12.5 \%)$

$25(62.5 \%)$

$8(20 \%)$

$6(15 \%)$

$1(2.5 \%)$

N - Number. \% - Percentage. 
Table 3. Continued...

\begin{tabular}{|c|c|c|}
\hline Questions & Responses & N (\%) \\
\hline How the acaricide was chosen & $\begin{array}{l}\text { Technician indication } \\
\text { Salesperson indication } \\
\text { Other responses }\end{array}$ & $\begin{array}{c}24(60 \%) \\
15(37.5 \%) \\
5(7.5 \%)\end{array}$ \\
\hline Mode of acaricide application & $\begin{array}{c}\text { Spraying } \\
\text { Poured on } \\
\text { Injection }\end{array}$ & $\begin{array}{l}38(95 \%) \\
35(87.5 \%) \\
17(42.5 \%)\end{array}$ \\
\hline In the case of spraying, this is done using & $\begin{array}{l}\text { Backpack pump } \\
\text { Electric pump }\end{array}$ & $\begin{array}{r}36(90 \%) \\
4(10 \%)\end{array}$ \\
\hline Endectocide is used & $\begin{array}{l}\text { No } \\
\text { Yes }\end{array}$ & $\begin{array}{l}22(55 \%) \\
18(45 \%)\end{array}$ \\
\hline How often is endectocide used? & $\begin{array}{c}\text { Twice a year } \\
\text { Six times a year } \\
\text { Four times a year (quarterly) } \\
\text { Once a month } \\
\text { Three times a year }\end{array}$ & $\begin{array}{l}(44.5 \%) \\
(28 \%) \\
(11 \%) \\
(11 \%) \\
(5.5 \%)\end{array}$ \\
\hline $\begin{array}{l}\text { In the case of injectable or pour-on products, } \\
\text { how do you calculate the dose? }\end{array}$ & $\begin{array}{l}\text { Visual estimation } \\
\text { Weighing }\end{array}$ & $\begin{array}{c}39(97.5 \%) \\
1(2.5 \%)\end{array}$ \\
\hline $\begin{array}{l}\text { Do you respect the resting period for discarding } \\
\text { the milk? }\end{array}$ & $\begin{array}{l}\text { No } \\
\text { Yes }\end{array}$ & $\begin{array}{l}24(60 \%) \\
16(40 \%)\end{array}$ \\
\hline Have you ever had problems with the acaricide? & $\begin{array}{l}\text { Yes } \\
\text { No }\end{array}$ & $\begin{array}{l}29(72.5 \%) \\
11(27.5 \%)\end{array}$ \\
\hline What problems? & $\begin{array}{c}\text { It failed } \\
\text { Animal intoxication }\end{array}$ & $\begin{array}{r}29(100 \%) \\
1(3.4 \%)\end{array}$ \\
\hline Last acaricide used & $\begin{array}{c}\text { Mixture of groups (organophosphate }+ \text { pyrethroids) } \\
\text { Fluazuron } \\
\text { Pyrethroids } \\
\text { Fipronil } \\
\text { Amidines } \\
\text { Macrocyclic lactones } \\
\text { Diflubenzuron } \\
\text { Flumethrin }\end{array}$ & $\begin{aligned} & 13(32.5 \%) \\
& 8(20 \%) \\
& 6(15 \%) \\
& 4(10 \%) \\
& 3(7.5 \%) \\
& 3(7.5 \%) \\
& 2(5 \%) \\
& 1(2.5 \%)\end{aligned}$ \\
\hline Penultimate acaricide used & $\begin{array}{c}\text { Mixture of groups (organophosphate }+ \text { pyrethroids) } \\
\text { Pyrethroids } \\
\text { Amidines } \\
\text { Macrocyclic lactones } \\
\text { Fluazuron } \\
\text { Fipronil }\end{array}$ & $\begin{array}{r}14(35 \%) \\
8(20 \%) \\
6(15 \%) \\
6(15 \%) \\
4(10 \%) \\
2(5 \%)\end{array}$ \\
\hline Antepenultimate acaricide used & $\begin{array}{c}\text { Mixture of groups (organophosphate }+ \text { pyrethroids) } \\
\text { Pyrethroids } \\
\text { Macrocyclic lactones } \\
\text { Amidines } \\
\text { Fluazuron } \\
\text { Fipronil } \\
\text { Organophosphate }\end{array}$ & $\begin{aligned} 13 & (32.5 \%) \\
9 & (22.5 \%) \\
7 & (17.5 \%) \\
6 & (15 \%) \\
3 & (7.5 \%) \\
1 & (2.5 \%) \\
1 & (2.5 \%)\end{aligned}$ \\
\hline Do you use any alternative for tick control? & $\begin{array}{l}\text { No } \\
\text { Yes }\end{array}$ & $\begin{array}{r}35(87.5 \%) \\
5(12.5 \%)\end{array}$ \\
\hline
\end{tabular}

$\mathrm{N}$ - Number. \% - Percentage.

of about 40 cows and 100 cattle in total (Table 1). Most of them covered areas of less than 57.7 ha (Table 1) and used hired labor (62.5\%) comprising one employee (59.3\%, Table 2).

Most of the farmers had been involved in dairy activity for more than 20 years (Table 1). The region studied can be characterized as a mixed exploitation area (meat and milk) and dairy activity is a major profit-generator, contributing at least $50 \%$ of the family income (Table 1), thus showing the importance of this activity for the region.
A significant number of the farmers were using FTAI (40\%), thus demonstrating their desire to implement genetic breeding programs and use technology (PAGANI, 2012). This has resulted from intensive technical assistance provided by CATI, the official extension education body of the State of São Paulo. Half of the farms were participating in the milk program developed by this government institution: this encourages use of technologies, such as FTAI, zootechnical bookkeeping and pasture management, among others. 
Table 4. Characterization of 40 dairy farms in the northwestern region of the State of São Paulo with regard to controlling other parasites.

\begin{tabular}{lcc}
\hline \multicolumn{1}{c}{ Questions } & Responses & N (\%) \\
\hline Deworming of animals & Yes & $40(100 \%)$ \\
& Twice & $25(62.5 \%)$ \\
How many times per & Three & $6(15 \%)$ \\
year? & Four & $4(10 \%)$ \\
& Monthly & $3(7.5 \%)$ \\
Treatment of horn fly & Six & $2(5 \%)$ \\
Treatment of botfly & Yes & $26(65 \%)$ \\
Treatment of screwworm & No & $14(35 \%)$ \\
& No & $40(100 \%)$ \\
Treatment of other ticks & No & $24(60 \%)$ \\
Treatment of coccidiosis & Yes & $16(40 \%)$ \\
& No & $40(100 \%)$ \\
& No & $30(75 \%)$ \\
& Yes & $10(25 \%)$ \\
\hline
\end{tabular}

$\mathrm{N}$ - Number. \% - Percentage.

On $60 \%$ of the farms, there was no entry of animals from outside (Table 2), which is interesting given that the cattle trade can contribute towards increasing the entrance of tick population that is resistant to acaricides. Animals that are purchased may be parasitized by resistant strains of $R$. (B.) microplus. On the other hand, $92.5 \%$ of the farmers stated that animals that had recently been acquired were immediately incorporated into the herd (Table 2), which could increases disease dissemination and spread the resistant tick population.

From Table 3, it can be seen that $R$. (B.) microplus was a problem for most of the respondents. On the majority of the farms $(87.5 \%)$, acaricide was used very frequently: every 30 days or less; and on some farms, even as often as weekly. However, more than half $(65 \%)$ of the farmers considered that they were satisfied with their tick control. Given the increasing resistance of ticks to commercial products (DAHER et al., 2012; UENO et al., 2012; MENDES et al., 2011; FAZA et al., 2013), the fact that most of these farmers were satisfied with their tick control must have been due to the crossbreeding of their herds (European x Zebu), which was present on $82.5 \%$ of the farms (Table 2). Bertolucci (2010) also found that more than half (58.8\%) of the dairy producers in the south of the State of Minas Gerais reported that they were relatively satisfied with their tick control and, in that study too, crossbred cattle formed the majority (73.6\%). Crossbred European x Zebu cattle present greater resistance to tick infections and lower economic damage than pure European breeds (MADALENA, 2008). Holstein is one of the most tick-susceptible breeds (UTECH et al., 1978).

Most of the interviewees (82.5\%) did not have any knowledge about the tick life cycle and $75 \%$ did not know how to implement strategic control of this parasite (Table 3). Amaral et al. (2011a) concluded that the strategic control recommended by the EMBRAPA Dairy Cattle study group, in the State of Minas Gerais, was not easy to implement on farms. Mendes (2015) also found problems in implementing strategic tick control in the State of São Paulo, even with technical assistance from CATI Milk Project technicians. Farmers generally do not know important details of the biology of ticks, even though this knowledge is important for rational control (ROCHA et al., 2006).

Grass types like Mombaça and Tanzania (Megathyrsus Sin. Panicum) or Urochloa (Sin. Brachiaria) or Tifton (Cynodon) were cited as favoring occurrences of ticks (Table 3). This may have been due to the dense leaf cover over the soil that these grass types provide, thereby favoring the free-living phase of ticks, with shade and humidity in the soil, which are essential for the life cycle of cattle ticks (VERÍSSIMO, 2015).

On the other hand, pastures close to forestry were reported by $48.1 \%$ to be unfavorable for tick development. Barci (1997) stated that in an experimental area in Campinas, State of São Paulo, a cattle herd close to forestry had fewer ticks than others, and that many birds could be seen at that location. Birds are known to be tick predators (VERÍSSIMO, 2013). Confirming this reference, $92.5 \%$ of the respondents of this survey (Table 3 ) responded that they had observed the presence of some predators of ticks, and cited the cattle egret (Bubulcus ibis), chickens and other birds. In the survey by Rocha et al. (2006), 100\% of the farmers responded that they knew that ticks had predators.

Newly formed pastures were cited by $29.6 \%$ as being unfavorable towards ticks. It is known that animals on recently formed pastures are less parasitized by ticks (VERÍSSIMO et al., 1997a, b) and worms (ECHEVARRIA et al., 1993). The crop-to-pasture rotation system is therefore an excellent form of parasite control, since part of ticks' life cycle is completed in soil.

In the present survey, it was found that cattle tick control was being implemented without technical criteria. It was especially noted (Table 3) that $92.5 \%$ implemented control using visual observation of the presence of ticks. This criterion can be very variable, as observed by Rocha et al. (2011). High frequency of acaricide baths selects and propagates the allelic resistance gene, through selection pressure (BRITO et al., 2015). Santos et al. (2009) reported from the State of Rio Grande do Sul, Brazil, that farmers who applied acaricide more than four times a year selected resistant tick populations. Similar results were found by Rodriguez-Vivas et al. (2006), in Mexico.

Among the farmers interviewed, half of them applied acaricide to all animals at the same time, while the other half applied it only to the parasitized animals (Table 3). Martins et al. (2002) highlighted the importance of synchronized treatment for all animals on a farm as a control strategy. However, recently, because of ticks' genetic resistant to acaricides, selective tick control (partial selective treatment of $R$. (B.) microplus) has being adopted and studied as an alternative form of control with the objective of using less acaricide and thus delaying the emergence of genetic resistance. Molento et al. (2013) studied selective control in beef herds in the State of Rio Grande do Sul, and Signoretti et al. (2006), in crossbred dairy herds in the State of São Paulo, Brazil. This remains a polemic issue, and further knowledge and scientific proof are required. Nonetheless, partial selective treatment of $R$. (B.) microplus could be a way of using less acaricide, especially on farms with crossbred cattle possessing some Zebu traits.

In relation to application of acaricide (Table 3), most of the farmers applied the "bath" to the whole body; $77.5 \%$ of them did not restrain the animals during the application and $87.5 \%$ did not use individual protection devices, thus exposing the workers 
or the owners themselves to the toxic compounds from acaricides. The lack of any habit of using individual protection devices and the low degree of concern about poisoning from acaricide applications were also observed by Rocha et al. (2006), Bertolucci (2010) and Domingues et al. (2012) on farms in Minas Gerais and by Bello (2010) on farms in Rio de Janeiro. Cattle need to be restrained in order to do a good acaricide application, especially in relation to the ventral area of the animals, where most of the ticks are attached (RODRIGUES et al., 2015). This practice is very important, considering the concealed areas that ticks prefer: axillae, groin, belly, inside the ears, neck, perineum and chest. According to these last authors, the bath must be started at the rear of the animal and the last place where the product should be applied is inside the ears, because of the sensitivity of this area and the disquietude of the animals that are being treated.

Regarding the kind of product used (Table 3), 60\% followed the technician's indication and the change to another product was made when the first one no longer present any effectiveness (62.5\%). Similar responses were observed by Rocha et al. (2006, 2011) and Amaral et al. (2011b), during surveys in the State of Minas Gerais. One important finding needs to be noted: none of the farmers responded that they had chosen the acaricide according to efficiency test results. However, this should be the ideal criterion, given the resistance situation of products against ticks, which is becoming increasingly worse in this country.

Injectable products for tick control (endectocides) were less used $(42.5 \%)$ than pour-on formula $(87.5 \%)$ or baths $(95 \%)$ (Table 3). Nonetheless, use of endectocides is a matter of concern, given that Rodriguez-Vivas et al. (2006) reported that herds on which endectocides were used were at 5.92 times greater risk of developing tick resistance to these formulations than were herds on which these were not used. In the present study, when endectocide was applied, this was done at least twice a year (44.5\%) (Table 3), and was probably done together with the vaccination protocol for foot-and-mouth disease, in May and November, which is a common management method in Brazil. Worm control was done on $100 \%$ of the farms, usually twice a year (Table 4). Endectocides are commonly used in Brazil to control worms, and this is based on active macrocyclic lactone molecules. Mendes et al. (2008) observed the use of such products to control ticks in the Paraiba river valley region, State of São Paulo, a location where historical tick resistance had previously been reported (MENDES et al., 2001). These products have no indication for dairy cattle because of the large number of days for which milk has to be discarded. Another concern about injectable products is the dose estimate. Almost $100 \%$ of the farmers said that they used visual weight estimates and not measured weights (Table 3). Niciura et al. (2012) found that visual weight estimates for flocks of sheep were the main risk factor for the presence of resistant Haemonchus contortus. During a recent survey on ivermectin resistance on Mexican farms, Alegria-López et al. (2015) found that use of ivermectin promoted development of ivermectin resistance among both nematodes and cattle ticks.

The acaricide application method most often used was spraying (Table 3) and backpack pumps were the type of equipment most used (90\%). Rocha et al. (2006, 2011), Amaral et al. (2011b), and Domingues et al. (2012) also observed that the great majority of dairy farmers in Minas Gerais used backpack pumps to spray cattle. This equipment is considered to have low efficiency among the methods available, due mainly to the need to wet the animal's entire body. This requires a high volume of the product and great effort from the person who applies it, along with a high level of exposure to the product, which is toxic (RODRIGUES et al., 2015). On the other hand, the pour-on formula is very practical but more expensive. It was used by many of the interviewees (Table 3), but the dosage was estimated visually, rather than by measuring the real weight, which is a problem that has already been discussed above.

Regarding alternative sources for tick control (Table 3), only five farms (12.5\%) used this, and three of them used homeopathy. Farias et al. (2008) and Amaral et al. (2011b) also reported that producers were dependent on chemical control and consequently were subject to higher selection pressure, thus favoring selected strains of $R$. (B.) microplus (FAZA et al., 2013; BRITO et al., 2015). In the survey by Amaral et al. (2011b) in the State of Minas Gerais, use of alternative control methods such as homeopathy was cited by $3.1 \%$. The real viability of dairy systems without use of agrochemicals and with exclusive use of homeopathy has being demonstrated by Signoretti et al. (2010) and Müller \& Fülber (2013). This provides an alternative for farmers to reduce the number of baths given to the animals and decrease the selection pressure towards resistant tick populations.

With regard to period during which milk should be discarded, $60 \%$ did not obey this (Table 3 ). This was a high percentage, but lower than what was found by Bertolucci (2010). In their study, $89.5 \%$ of the interviewees in the south of the State of Minas Gerais did not discard the milk after acaricide application. This situation needs to be resolved with farmers, given that milk can carry toxic residues from the acaricide used. Milk is a food source that is particularly recommended for infants and older people, and such practices may compromise their health, in the event of contamination.

Regarding problems with the acaricides used, $72.5 \%$ of the farmers of the present study noticed problems relating to lack of efficiency. This demonstrates that there is a need to encourage use of acaricide efficiency tests. These tests are run by several official research bodies in this country, and most of them are free of charge. In the survey conducted by Bertolucci (2010), the problem most cited was intoxication of the animal by the acaricide $(46.6 \%)$ followed by resistance to the product $(44.8 \%)$ and intoxication of humans $(6.9 \%)$.

When the farmers of the present study were asked about the type of acaricide used, mixtures of chemicals were the type most cited: $32.5 \%$ in the last, $35 \%$ in the penultimate and $32.5 \%$ in the antepenultimate application (Table 3). In in vitro assays, Spagnol et al. (2010), Pereira (2006) and Camillo et al. (2009) determined the best efficiency for mixed chemical groups in relation to ticks tested in municipalities of the States of Bahia, São Paulo and Rio Grande do Sul, respectively. Domingues et al. (2012) found that mixtures of pyrethroids and organophosphates were more used for tick and hornfly control by producers in the Triângulo Mineiro and Alto Paranaíba regions of Minas Gerais.

Treatment for hornfly (Haematobia irritans) was administered on $65 \%$ of the farms of the present study (Table 4). This is important 
information, since the chemical products for controlling these two parasites are similar. Farias et al. (2008) and Santos et al. (2009) found a similar situation in Rio Grande do Sul and Domingues et al. (2012) in Minas Gerais. Care is required with regard to cross-selection for the two parasites. Moreover, when the aim is only to control hornflies, the amount of product required is very low, which is a factor requiring greater surveillance of tolerant ticks.

The botfly (Dermatobia hominis) seems not to be a problem in the region studied, given that none of the interviewees were implementing treatment for this parasite, as well as other tick species. Forty percent reported problems with screwworm (Cochliomyia hominivorax), which was expected because high rates of tick infection provide ideal conditions for this parasite (RECK et al., 2014). Regarding coccidiosis, 75\% did not report any problems.

When asked about tick resistance problems relating to acaricides, 95\% showed knowledge of the issue, but only $10 \%$ knew about or used the efficiency test, which has been provided free of charge by EMBRAPA Dairy Cattle for more than ten years and $40 \%$ said that they knew about the test but had never used it. According to Amaral et al. (2011a), farmers only rarely know about the efficiency test, despite all the efforts of the EMBRAPA Dairy Cattle program to publicize it through the media. Daher et al. (2012) reported that the test indicates the right product for tick control and also detects occurrences of resistance. According to those authors, occurrences of resistance are related to risk factors in the technologies adopted by farmers, such as artificial insemination, mechanical milking and use of the Holstein breed, among others.

Efficiency tests had been implemented by $10 \%$ of the farmers of the present study. Among the products that presented high efficiency $(>80 \%)$ in these tests, mixed chemical groups can be highlighted. Regarding the products with low efficiency $(<80 \%)$, pyrethroids stand out. An acaricide based on cypermethrin and chlorpyrifos was the most efficient one used by Daher et al. (2012), who found multiple resistance on about $92.2 \%$ of the farms studied. In a study on four farms at Bady Bassitt and one at Ipiguá, close to our region of study, Ueno et al. (2012) found that a mixture of the same chemical groups (cypermethrin and chlorpyrifos) showed the highest efficiency (78.9\%), but did not differ statistically from a mixture of two organophosphate bases and a product based on amitraz. In their survey, like in the present study and most other surveys conducted in Brazil, the acaricide was chosen without any technical criteria, based on recommendations from salespersons or from other producers; it was applied in accordance with the level of infestation, at high frequencies during the year; all the farmers interviewed in their survey used backpack pumps for spraying and some farmers said that they had used growth inhibitors, which are prohibited for dairy cattle.

In the present survey, technical assistance was found to be used frequently, by $75 \%$ of the farms, and a further $22.5 \%$ made use of sporadic assistance, thus totaling $92.5 \%$ of the farms that received visits from technical experts. Therefore, information about tick control needs to be passed through the technical experts and then to the farmers through talks or field-days, which was the means through which the largest proportion of the interviewees (32\%) said that they got information. Moreover, $40 \%$ of the farmers had bachelor's degrees and another 30\% had completed high school education, thus showing that the farmers interviewed had a good educational level and with have found it easier to comprehend dairy politics and production systems.

In the study conducted by Rocha et al. (2012) most of the interviewees had only reached elementary school level (54\%), but this did not show any correlation with the efficiency of tick control. However, Santos et al. (2009), in the State of Rio Grande do Sul, observed that illiterate farmers, or the ones only with elementary school level, presented a threefold greater chance of failure in tick control procedures than farmers with higher education level.

In order to improve tick control, pasture must remain at rest for at least 60 days, according to Furlong (1998). This length of time is more than is generally used in paddock rotational systems (SANTOS et al., 2000). However, a study on tick control conducted on farms attended by the CATI Milk Project (MENDES, 2015), which involved technologies for milk production on pasture that have already been cited in this text, showed that these technologies should indirectly contribute towards tick control. It is known that urea has a positive effect in relation to fertilization cover for tick control (WANDERLEY et al., 2015), and many of the farmers of this study used it in their practice. The urea granules come into contact with teleogynes and cause their death, thus not allowing oviposition (CUNHA et al., 2010). Moreover, good pasture management practice keeps herds in an excellent nutritional state, which is essential for maintaining animals' tick resistance at a good level (SUTHERST et al., 1983).

Nowadays, one of the technical experts' concerns is to increase farm yield. One way to achieve this is to start using technologies such as the ones cited in this study, which were used by workers following the CATI Milk Project, thus enabling higher stocking rates. On other hand, higher stocking rates could hamper tick control if there is a lack of awareness of some aspects of this: for example, acaricide bath efficiency, use of effective acaricides and use of more resistant breeds. This set of technologies will enable sustainable milk production on pasture and good control over cattle tick and other parasites.

\section{Conclusions}

The interviewees' perceptions and level of information about tick control was considered to be low, and there was a lack of technical criteria for tick control.

Education programs and capacitation need to be applied through seminars, short-term courses and lectures. Illustrative folders need to be given to the technical experts who provide assistance to farmers, so that information can be transmitted to the dairy community. This is important for ensuring rational and sustainable tick control.

The farmers visited for this study generally had a high technological level for milk production on pasture. They form an example to be followed in other regions of the State of São Paulo and throughout Brazil or other tropical regions of the world, in which technical assistance is provided in order to increase milk production in tropical areas in a sustainable manner. 


\section{Acknowledgements}

To the producers who participated in this survey.

\section{References}

Alegria-López MA, Rodríguez-Vivas RI, Torres-Acosta JFJ, Ojeda-Chi MM, Rosado-Aguilar JA. Use of ivermectin as endoparasiticide in tropical cattle herds generates resistance in gastrointestinal nematodes and the tick Rhipicephalus microplus (Acari: Ixodidae). J Med Entomol 2015; 52(2): 214-221. http://dx.doi.org/10.1093/jme/tju025. PMid:26336306.

Amaral MA, Rocha CM, Faccini JL, Furlong J, Monteiro CM, Prata MC. Strategic control of cattle ticks: milk producers' perceptions. Rev Bras Parasitol Vet 2011a; 20(2): 148-154. http://dx.doi.org/10.1590/ S1984-29612011000200010. PMid:21722490.

Amaral MA, Rocha CM, Faccini JL, Furlong J, Monteiro CM, Prata MC. Perceptions and atitudes among milk producers in Minas Gerais regarding cattle tick biology and control. Rev Bras Parasitol Vet 2011b; 20(3): 194-201. http://dx.doi.org/10.1590/S1984-29612011000300003. PMid:21961747.

Barci LAG. Controle biológico do carrapato dos bovinos Boophilus microplus (Acari, Ixodidae) no Brasil. Arq Inst Biol 1997; 64(1): 95-101.

Bello ACPP. A representação social do saber de trabalhadores rurais sobre o controle das parasitoses em propriedades produtoras de leite [Thesis]. Belo Horizonte: Universidade Federal de Minas Gerais; 2010.

Bertolucci AV. Percepção dos produtores do sul de Minas Gerais sobre a importância e formas de controle do carrapato Rhipicephalus (Boophilus) microplus (Canestrini, 1887) [Dissertation]. Lavras: Universidade Federal de Lavras; 2010.

Brito LG, Barbieri FS, Oliveira MCS, Huacca MF. Diagnóstico de resistência às bases carrapaticidas em populaçóes do carrapato dos bovinos. In: Veríssimo CJ. Resistência e controle do carrapato-do-boi. Nova Odessa: Instituto de Zootecnia; 2015. p. 2-28.

Camillo G, Vogel FF, Sangioni LA, Cadore GC, Ferrari R. Eficiência in vitro de acaricidas sobre carrapatos de bovinos no Estado do Rio Grande do Sul, Brasil. Cienc Rural 2009; 39(2): 490-495. http://dx.doi. org/10.1590/S0103-84782008005000082.

Cunha AP, Bello ACPP, Domingues LN, Martins JR, Oliveira PR, Freitas CMV, et al. Effects of urea on the cattle tick Rhipicephalus (Boophilus) microplus (Acari: Ixodidae). Vet Parasitol 2010; 174(3-4): 300-304. http:// dx.doi.org/10.1016/j.vetpar.2010.08.036. PMid:20855169.

Daher DO, Bertolucci AV, Lopes E, Guimarães AM, Rocha CMBM. Fatores associados à resistência do Rhipicephalus (Boophilus) microplus (CANESTRINI, 1887) no sul de Minas Gerais. Rev Verde 2012; 7(1): 102-115.

Domingues LN, Bello ACPP, Cunha AP, Leite PVB, Barros ATM, Leite RC. Caracterização do controle de Haematobia irritans e Rhipicephalus (Boophilus) microplus no Triângulo Mineiro e Alto Paranaíba, Minas Gerais. Pesqui Vet Bras 2012; 32(12): 1246-1252. http://dx.doi.org/10.1590/ S0100-736X2012001200006.

Echevarria FAM, Armour J, Duncan JL, Pinheiro AC. Use of reseeded pastures as an aid in the control of gastrointestinal nematodes. Vet Parasitol 1993; 50(1-2): 151-155. http://dx.doi.org/10.1016/03044017(93)90016-G. PMid:8291191.
Farias NA, Ruas JL, Santos TRB. Análise da eficácia de acaricidas sobre o carrapato Boophilus microplus, durante a última década, na regiáo sul do Rio Grande do Sul. Cienc Rural 2008; 38(6): 1700-1704. http://dx.doi. org/10.1590/S0103-84782008000600032.

Faza AP, Pinto ISB, Fonseca I, Antunes GR, Monteiro CMO, Daemon $\mathrm{E}$, et al. A new approach to characterization of the resistance of populations of Rhipicephalus microplus (Acari: Ixodidae) to organophosphate and pyrethroid in the State of Minas Gerais, Brazil. Exp Parasitol 2013; 134(4): 519-523. http://dx.doi.org/10.1016/j.exppara.2013.04.006. PMid:23639866.

Ferreira RM. A definição de pequena propriedade rural [online]. 2015 [cited 2015 Mar 26]. Available from: http://fjradvogados.jusbrasil.com. br/noticias/126322854/a-definicao-de-pequena-propriedade-rural

Furlong J. Poder infestante de larvas de Boophilus microplus (Acari: Ixodidae) em pastagem de Melinis minutiflora, Brachiaria decumbens e Brachiaria mutica. Cienc Rural 1998; 28(4): 635-640. http://dx.doi. org/10.1590/S0103-84781998000400016.

Grisi L, Leite RC, Martins JRS, Barros ATM, Andreotti R, Cançado PHD, et al. Reassessment of the potential economic impact of cattle parasites in Brazil. Rev Bras Parasitol Vet 2014; 23(2): 150-156. http:// dx.doi.org/10.1590/S1984-29612014042. PMid:25054492.

Kunz SE, Kemp DH. Insecticides e acaricides: resistance and environmental impact. Rev Sci Tech 1994; 13(4): 1249-1286. http://dx.doi.org/10.20506/ rst.13.4.816. PMid:7711312.

Madalena FE. Estratégias de uso de recursos genéticos visando melhorar a qualidade do leite e derivados [online]. 2008 [cited 2015 Mar 26]. Available from: http://javali.fcav.unesp.br/sgcd/Home/departamentos/zootecnia/ SANDRAAIDARDEQUEIROZ/sbma_paper_madalena.pdf

Martins JR, Evans DE, Ceresér VH, Correa BL. Partial strategic tick control within a herd of European breed cattle in the State of Rio Grande do Sul, southern Brazil. Exp Appl Acarol 2002; 27(3): 241-251. http:// dx.doi.org/10.1023/A:1021656927165. PMid:12593589.

Mendes MC, Lima CKP, Nogueira AHC, Yoshihara E, Chiebao DP, Gabriel FHL, et al. Resistance to cypermethrin, deltamethrin and chlorpyriphos in populations of Rhipicephalus (Boophilus) microplus (Acari: Ixodidae) from small farms of the State of São Paulo, Brazil. Vet Parasitol 2011; 178(3-4): 383-388. http://dx.doi.org/10.1016/j.vetpar.2011.01.006. PMid:21306827.

Mendes MC, Pinto Lima CK, Pereira JR. Práticas de manejo para o controle do carrapato Rhipicephalus (Boophilus) microplus (Acari: Ixodidae) em propriedades localizadas na região de Pindamonhangaba, Vale do Paraíba, São Paulo. Arq Inst Biol 2008; 75(3): 371-373.

Mendes MC, Veríssimo CJ, Kaneto CN, Pereira JR. Bioassays for measuring the acaricides susceptibility of cattle tick Boophilus microplus (Canestrini, 1887) in São Paulo State, Brazil. Arq Inst Biol 2001; 68(2): 23-27.

Mendes MC. Controle estratégico do carrapato dos bovinos Rhipicephalus (Boophilus) microplus, no Estado de São Paulo. In: Veríssimo CJ. Resistência e controle do carrapato-do-boi. Nova Odessa: Instituto de Zootecnia; 2015. p. 114-123.

Minitab. User's guide 2: data analysis and quality tools. Release 13 for Windows. 2000. [cited 2015 May 12]. Available from: https://shamsulsarip. files.wordpress.com/2015/07/minitab_book.pdf

Molento MB, Fortes FS, Buzatti A, Kloster FS, Sprenger LK, Coimbra E, et al. Partial selective treatment of Rhipicephalus microplus and breed resistance variation in beef cows in Rio Grande do Sul, Brazil. Vet Parasitol 
2013; 192(1-3): 234-239. http://dx.doi.org/10.1016/j.vetpar.2012.10.021. PMid:23219046.

Müller SF, Fülber VM. A homeopatia na pecuária leiteira: da capacitação aos resultados práticos. Cad Agroecol 2013; 8(2): 1-5.

Niciura SCM, Veríssimo CJ, Gromboni JGG, Rocha MIP, Mello SS, Barbosa CMP, et al. F200Y polymorphism in the $\beta$-tubulin gene in field isolates of Haemonchus contortus and risk factors of sheep flock management practices related to anthelmintic resistance. Vet Parasitol 2012; 190(3-4): 608-612. http://dx.doi.org/10.1016/j.vetpar.2012.07.016. PMid:22858226.

Pagani C No., editor. CATI leite. Campinas: CATI; 2012.

Pereira JR. Eficácia in vitro de formulaçôes comerciais de carrapaticidas em teleóginas de Boophilus microplus coletadas de bovinos leiteiros do Vale do Paraíba, Estado de São Paulo. Rev Bras Parasitol Vet 2006; 15(2): 45-48. PMid:16834895.

Pereira MC, Labruna MB, Szabó MPJ, Klafke GM. Rhipicephalus (Boophilus) microplus: biologia, controle e resistência. São Paulo: Med Vet; 2008.

Reck J, Marks FS, Rodrigues RO, Souza UA, Webster A, Leite RC, et al. Does Rhipicephalus microplus tick infestation increase the risk for myiasis caused by Cochliomyia hominivorax in cattle? Prev Vet Med 2014; 113(1): 5962. http://dx.doi.org/10.1016/j.prevetmed.2013.10.006. PMid:24176137.

Rezende MVO, Okano W, Barca FA Jr, Lopes FG, Koetz C Jr, Santana $\mathrm{EHW}$, et al. Determinação de resíduo de cipermetrina em fígado bovino por meio de cromatografia líquida acoplada à espectrometria de massas (LC-MS). Rev Agroneg Meio Amb 2013; 6(2): 261-270.

Rocha CMBM, Bruhn FRP, Leite RC, Guimarães AM, Sampaio IB, Oliveira PR. Principal component analysis on the perceptions of milk producers about Rhipicephalus (Boophilus) microplus control in Minas Gerais. Rev Bras Parasitol Vet 2012; 21(3): 224-231. http://dx.doi.org/10.1590/S198429612012000300009. PMid:23070431

Rocha CMBM, Leite RC, Bruhn FRP, Guimarães AM, Furlong J. Perceptions about the biology of Rhipicephalus (Boophilus) microplus among milk producers in Divinópolis, Minas Gerais. Rev Bras Parasitol Vet 2011; 20(4): 289-294. http://dx.doi.org/10.1590/S1984-29612011000400006. PMid:22166382.

Rocha CMBM, Oliveira PR, Leite RC, Cardoso DL, Calic SB, Furlong J. Percepção dos produtores de leite do município de Passos, MG, sobre o carrapato Boophilus microplus (Acari: Ixodidae), 2001. Cienc Rural 2006; 36(4): 1235-1242. http://dx.doi.org/10.1590/S0103-84782006000400029.

Rodrigues DS, Leite RC. Impacto econômico de Rhipicephalus (Boophilus) microplus: estimativa de redução de produção de leite. Arq Bras Med Vet Zootec 2013; 65(5): 1570-1572. http://dx.doi.org/10.1590/S010209352013000500039 .

Rodrigues DS, Muller RPB, Leite RC. Aplicação de carrapaticida em bovinos. In: Veríssimo CJ. Resistência e controle do carrapato-do-boi. Nova Odessa: Instituto de Zootecnia; 2015. p. 29-56.

Rodriguez-Vivas RI, Alonso-Díaz MA, Rodríguez-Arevalo F, Fragoso-Sanchez H, Santamaria VM, Rosario-Cruz R. Prevalence and potencial risk factors for organophosphate and pyrethroid resistance in Boophilus microplus ticks on cattle ranches from the State of Yucatan, México. Vet Parasitol 2006; 136(3-4): 335-342. http://dx.doi.org/10.1016/j.vetpar.2005.05.069. PMid:16413971.

Santos JCB Jr, Furlong J, Daemon E. Controle de carrapato Boophilus microplus (Acari: Ixodidae) em sistemas de produção de leite da microrregião fisiográfica fluminense do Grande Rio - Rio de Janeiro. Cienc Rural 2000; 30(2): 305-311. http://dx.doi.org/10.1590/S0103-84782000000200018.
Santos TRB, Farias NAR, Cunha NA Fo, Pappen FG, Vaz IS Jr. Abordagem sobre o controle do carrapato Rhipicephalus (Boophilus) microplus no sul do Rio Grande do Sul. Pesqui Vet Bras 2009; 29(1): 65-70. http://dx.doi. org/10.1590/S0100-736X2009000100010.

São Paulo. Governo do Estado. Secretaria de Agricultura e Abastecimento. Instituto de Economia Agrícola. Coordenadoria de Assistência Técnica Integral. Levantamento censitário de unidades de produção agrícola do Estado de São Paulo - LUPA 2007/2008 [online]. São Paulo: SAA/CATI/IEA; 2008. [cited 2013 Dec 05]. Available from: http://www.cati.sp.gov.br/projetolupa

São Paulo. Governo do Estado. Secretaria do Meio Ambiente. Módulo fiscal [online]. São Paulo: Secretaria do Meio Ambiente; 2014. [cited 2016 Apr 08]. Available from: http://www.ambiente.sp.gov.br/sicar/files/2014/05/ Modulos-Fiscais-por-Municipio.pdf

Signoretti RD, Faria MH, Veríssimo CJ, Oliveira JV, Resende FD, Mariguela MJF. Controle seletivo do carrapato em bovinos leiteiros. Biológico 2006; 68(Suppl): 192-195.

Signoretti RD, Veríssimo CJ, Souza FHM, Oliveira EM, Dib V. Aspectos produtivos e sanitários de vacas mestiças leiteiras tratadas com produtos homeopáticos. Arq Inst Biol (Sao Paulo) 2010; 77(4): 625-633.

Silva TPP, Moreira JC, Peres F. Serão os carrapaticidas agrotóxicos? Implicaçóes na saúde na percepçáo de riscos de trabalhadores da pecuária leiteira. Cien Saude Colet 2012; 17(2): 311-325. http://dx.doi.org/10.1590/ S1413-81232012000200006. PMid:22267027.

Spagnol FH, Paranhos EB, Albuquerque GR. Avaliação in vitro da ação de acaricidas sobre Rhipicephalus (Boophilus) microplus Canestrini, 1887 (Acari:Ixodidae) de bovinos leiteiros no município de Itamaraju, Bahia, Brasil. Cienc Anim Bras 2010; 11(3): 731-736.

Sutherst RW, Kerr JD, Maywald GF, Stegeman DA. The effect of season and nutrition on the resistance of cattle to the tick Boophilus microplus. Aust J Agric Res 1983; 34(3): 329-339. http://dx.doi.org/10.1071/AR9830329.

Ueno TEH, Mendes EEB, Pomaro SHK, Lima CKP, Guilloux AGA, Mendes MC. Sensitivity profile of Rhipicephalus (Boophilus) microplus ticks of dairy cattle to acaricides in small farms in the northwestern São Paulo State, Brazil. Arq Inst Biol 2012; 79(2): 177-183. http://dx.doi. org/10.1590/S1808-16572012000200005.

Utech KBW, Wharton RH, Kerr JD. Resistance to Boophilus microplus (Canestrini) in different breeds of cattle. Aust J Agric Res 1978; 29(9): 885-895. http://dx.doi.org/10.1071/AR9780885.

Veríssimo CJ, Silva RG, Oliveira AAD, Ribeiro WR, Rocha UF. Resistência e suscetibilidade de bovinos leiteiros mestiços ao carrapato Boophilus microplus. B Industr Anim 1997a; 54(2): 1-10.

Veríssimo CJ, Silva RG, Oliveira AAD, Ribeiro WR, Rocha UF. Contagens de ínstares do carrapato Boophilus microplus em bovinos mestiços. B Industr Anim 1997b; 54(2): 19-24.

Veríssimo CJ. Controle biológico do carrapato do boi, Rhipicephalus (Boophilus) microplus no Brasil. Rev Educ Cont CRMV-SP 2013; 11(1): 14-23.

Veríssimo CJ. Fatores que afetam a fase de vida livre de carrapatos. In: Verissimo CJ. (Org.) Controle de carrapatos nas pastagens. 2nd ed. Nova Odessa: Instituto de Zootecnia; 2015. p. 2-17.

Wanderley RPB, Ribeiro ACCL, Rodrigues DS, Leite RC. Adubação com ureia em pastejo rotacionado e seu efeito no controle do Rhipicephalus (Boophilus) microplus. In: Verissimo, C. Controle de carrapatos nas pastagens. 2nd ed. Nova Odessa: Instituto de Zootecnia; 2015. p. 100-106. 